\title{
Arqueología de la mímesis humana. La condición paradójica de la acción imitativa
}

\section{(Archaeology of human mimesis. The paradoxical condition of imitative action)}

\author{
Castor M. M. BARTOlomé Ruiz
}

Recibido: 19 de agosto de 2014

Aceptado: 27 de abril de 2015

\section{Resumen}

Este ensayo presenta un análisis arqueo-genealógico de la mímēsis humana en dos momentos: en su arkhē pre-socrático y en la interpretación platónica de la misma. El mismo desarrolla la tesis de que la mímēsis es una facultad humana atravesada por la condición paradójica a partir de la cual es factible su instrumentalización alienante de las conciencias, pero también su uso creativo para producir diferencias de lo semejante y semejanzas de lo diferente. La condición paradójica impide el reduccionismo de la mímēsis a una única perspectiva. Se concluye el ensayo con algunos desdoblamientos críticos del carácter paradójico de la mímēsis en nuestro presente.

Palabras clave: Mímesis, pre-socráticos, Platón, paradoja agonística.

\begin{abstract}
This paper presents an archaeological analysis of human mimesis in two stages: in the pre-Socratic arkhe and Platonic interpretation of it. The proposition of this paper is that mimesis is a human faculty crossed by the paradoxical condition from which it is possible to alienate and manipulate the consciences, but also is possible the creative use to produce the differences of similar and similarities of the different. The paradoxical condition prevents the reductionism of mimesis to a single perspective. This paper concludes with some critical references about the paradoxical nature of mimesis in our present.
\end{abstract}

Keywords: Mimesis, pre-Socratics, Plato, agonistic paradox. 


\section{Introducción}

1. El concepto de mímesis recorre la propia historia de la filosofía. Su temprana presencia en la cultura de la Grecia antigua, con resonancia en los debates filosóficos de la Grecia pre-socrática, así como su actual importancia muestran que estamos ante una realidad humana que excede las definiciones conceptuales simples y no se deja encorsetar en discursos conclusivos o totalizantes.

El objetivo de este ensayo es presentar una breve arqueología genealógica de la mímesis a partir de dos momentos originales de su tematización histórica, mostrando cómo se manifiesta en ellos su condición paradójica y cómo esa condición se hace presente en algunos desdoblamientos de la contemporaneidad. En un primer momento, realizaremos una excavación arqueología de la mímesis en el pensamiento pre-socrático; en un segundo momento, rastrearemos el modo cómo Platón se apropió de la mímesis conceptuándola de forma peyorativa, sin conseguir negar la potencia mimética de la filosofía; concluiremos analizando algunos desdoblamientos contemporáneos de la condición paradójica de la mímesis.

Los dos recortes arqueo-genealógicos clásicos que proponemos son importantes por dos aspectos, entre otros. Primeramente, ellos representan el marco original sobre la tematización de la mímesis, que dará lugar a una compleja andadura filosófica posterior. En segundo lugar, en la arqueología de esas visiones originarias de la mímesis se evidencia su dimensión paradójica, que impide su enclaustramiento conceptual en una única comprensión axiológica, política o ética. La tesis que proponemos es que la mímesis es una dimensión humana que se manifiesta históricamente atravesada por una tensión paradójica, tensión que, a su vez, es constitutiva de la acción humana. Siendo la mímesis una dimensión de la acción humana, la tensión paradójica la torna polivalente. Por ello, no se puede abolir la mímesis sin menoscabar la potencialidad de la acción humana, pero se puede direccionar el sentido de la imitación y el modo de reproducir las semejanzas.

El objetivo de este ensayo no es realizar una exégesis exhaustiva de cada uno de los autores mencionados, sino trazar, a través de la arqueo-genealogía, el hilo conductor de un análisis crítico por medio del cual se puede enhebrar la tensión agónica de la mímesis y su potencialidad multi-facetada. Ello nos permitirá entender cómo en la contemporaneidad la tensión agónica continúa apareciendo en las diversas interpretaciones de la mímesis que ora la juzgan una actitud alienante, ora la destacan como facultad creativa. Esa tensión no se soluciona anulando uno de los extremos o diluyéndolos entre sí, ni tampoco se resuelve en una síntesis tercera donde convergen los puntos de tensión. La tensión es constitutiva de la potencia creadora, que abre la acción humana para la imprevisibilidad. No podemos anular la tensión agonística sin negar la potencia de la acción, y la problemática de la mímesis está atravesada por esta tensión insoluble. La tensión es paradójica, por ello la 
mímesis es una práctica humana abierta a la potencia de la acción que puede direccionarse en uno u otro sentido.

El alcance del estudio arqueo-genealógico que proponemos en este ensayo debe ser comprendido desde la interpelación de nuestro presente, en el cual la dimensión mimética vuelve a actualizarse de diversas formas. Específicamente, se ha problematizado el mimetismo en varios contextos contemporáneos, entre ellos el marco de la biopolítica, que no cesa de utilizar la mímesis como medio para alienar comportamientos, normalizándolos a través de la imitación. Pero también, y paradójicamente, la mímesis puede revelarse como una forma de insurgencia biopolítica que aprende imitando e imita aprendiendo.

\section{La mímesis pre-socrática}

2. Cuando Platón escribe, la mímesis ya era una temática con una larga historia de problematizaciones. Ni Platón ni Aristóteles definieron propiamente el término mímēsis. El propio significado del término griego mímēsis tiene acepciones diversas que pueden inducir a comprensiones diferentes sobre la acción que designa ${ }^{1}$. La expresión mimētikai tékhnai (artes miméticas), acuñada por Platón en el Sofista, y que sirvió de base para su problematización filosófica, está precedida por una historicidad que no puede ser desconsiderada. Aunque el legado platónico de la mímesis tuvo una influencia mayor, autores como Homero, Sófocles, Esquilo, Eurípides, Demóstenes, Gorgias, Aristófanes, Heródoto, Tucídides, Demócrito o Jenofonte, entre otros, tratan-del tema en sus obras. Para entender el legado semántico que recibimos sobre la mímesis, es necesario escavar en su reflexión pre-platónica, como arkhē de la mímesis en nuestra tradición filosófica y cultural.

El substantivo mímesis deriva del verbo mimeîsthai que a su vez procede del substantivo mîmos ${ }^{2}$. Hasta donde se ha conseguido saber, el vocablo "mîmos" se originó en Sicilia vinculado a las representaciones teatrales que los personajes realizaban, de tal forma que el substantivo designaba alguien que se asumía como personaje similar o semejante a otro ${ }^{3}$. Es probable que los mîmoi se realizasen en forma de danza, música o artes escénicas intentando traer para la escena un modelo que era conocido de todos 4 . Lo que el término originario "mimos" designaba era el arte

\footnotetext{
1 Else (1958), p. 74.

2 Sörbom (1996), p. 16-17.

3 Else sintetiza los sentidos de las palabras vinculadas al término $\mu \mu \varepsilon \imath \sigma \theta \alpha \imath$ (mimeĩsthai) en el siglo V a.C. en tres grupos: a) representación de apariencias, acciones y o expresiones de animales u hombres en la forma de actuación o simulación (mimoi); b) la imitación de las acciones de una persona por otra, sin actuar (mimo); c) la reproducción de la imagen de una persona o cosa (mimema). Else entiende que el primer sentido es el original y los demás son desdoblamientos del mismo. Else (1958), p. 76.

4 Wulf (2008), p. 56.
} 
escénico en sí asociado a personas pobres o de baja condición social, por ello es un vocablo raro en la literatura de la época ${ }^{5}$. El término mímesis es posterior y lo encontramos significando varios sentidos como la representación de animales o imitación de otros hombres, incluso con el sentido de imitar la efigie de una persona ${ }^{6}$. En la coyuntura de siglo V a.C, el término mímesis se refiere a la imitación de animales o personas a través de sonidos, imágenes o danza, recreando con ello las imágenes de las cosas o personas representadas ${ }^{7}$.

En sus inicios, ya encontramos la mímesis como una práctica que envuelve, por un lado, la imitación, y, concomitantemente, la creación. La tensión agonística ya aparece diseñada desde el comienzo en la mímesis, que no representa una mera copia, sino una perfecta creación. La mímesis es más perfecta cuanto mejor crea la semejanza. Los artistas que imitan (mîmoi) son valorados porque imitan con perfección. La perfección de la imitación requiere una creación, que exige crear la imitación. Al crear la imitación se desdobla la tensión agonística de la imitación creativa y de la creación imitadora. El valor de la mímesis no está en ser copia, sino en el acto creativo de imitar. Lo valioso de la mímesis es la acción creativa que imita.

Encontramos en los primeros restos arqueo-genealógicos originarios de la mimesis una tensión agonística que nunca la abandonará. En la mímesis pre-socrática ya se establece el entrecruzamiento paradójico de esta dimensión humana como encrucijada constitutiva de la propia acción mimética, que por extensión se aplica, de diferentes modos, a toda acción humana.

3. El verbo mimeîsthai fue evolucionando a lo largo del tiempo y adquiriendo varios significados asociados a la emulación o imitación de algo ${ }^{8}$. Una emulación que puede imitar ejemplarmente algo, pero también puede transformarse en disimulación para falsearlo. La mímesis puede ser una disimulación que en lugar de imitar emulando pretende falsear al original imitándolo disimuladamente. En este sentido, la mímesis será una forma de imitar falseando y deformando lo que se imita. De estos varios sentidos, prevaleció el significado de mímesis como forma de imitar algo o alguien identificándolo a través de alguna característica ejemplar. En la mímesis, entra en juego siempre la identificación y la identidad.

La disimilación o la emulación imitan igualmente. La disimulación imita disfrazando o falseando lo real, la emulación copia con la máxima fidelidad. En ambos casos, la mímesis conjuga la posibilidad de crear identidades diferentes: identificar-

\footnotetext{
5 Else (1958), p. 76.

6 Sörbom discuerda de Else y sustenta que mimeĩsthai no significaría la acción del actor, sino que indicaría el hecho de imitar al actor, de comportarse como un "mimo". Sörbom (1996), p. 24-37.

7 Wulf (2008), P. 57.

8 Sörbom entiende que la evolución se dio de dos formas: a) poco a poco se ampliaron los fenómenos a los cuales el término mimeĩsthai y sus correlatos era aplicado; b) el sentido metafórico de estos términos se fue ampliando, ya que para Sörbom el significado original de mimo designaba el acto de imitar al actor y su acción. Sörbom (1996), p. 24-37.
} 
se con el otro, ser otro9. Disimular o emular son posibilidades de la mímesis, ambas son prácticas miméticas que reflejan las posibilidades abiertas, incluso contradictorias, del ser de la mímesis. En ellas aparece la condición paradójica de la mímesis que puede operar de forma polivalente permaneciendo como acción mimética.

La escenificación mimética trae a la luz la tensión que existe entre semejanzas y diferencias, proximidad y distancia. Esta tensión también es paradójica porque al imitar no se anula la diferencia, sino que, en la imitación, algo se hace semejante de forma diferente. Lo diferente de lo semejante caracteriza la acción mimética como original y no como mera copia. De igual modo, la imitación mimética es agonística porque aproxima el sujeto de su modelo imitado, acorta la distancia pero no la anula. La acción mimética no anula la distancia entre el sujeto y su modelo, caso contrario no habría imitación sino identificación absoluta; el sujeto es distante y diferente de su modelo en el arte de imitarlo como él mismo. La mímesis aproxima distancias, pero no las anula. La distancia es constitutiva de la mímesis y permite crear aproximaciones diferenciadas. La mímesis se construye en el cruce de la proximidad distante y de la identidad diferente, no es pura identidad, pues no imitaría, ni puede ser mera diferencia porque no reflejaría nada de lo que pretende imitar. Ella es una práctica humana histórica que reconstruye una identidad semejante en lo diferente: imita diferenciando, diferencia imitando. Desde los orígenes de su tematización, vemos entrelazarse sus componentes agonísticos y paradójicos de la. Este cruce original de la práctica mimética se mantendrá como un polo de tensión arqueológico permanente e insuperable a lo largo de su historia.

\section{El mimetismo paradójico de Platón}

4. Es ampliamente conocida la crítica que Platón hizo de la mímesis. Pero, como veremos, la posición crítica de Platón a muchas formas de mímesis es, concomitantemente, una comprensión positiva de algunas prácticas imitativas. La condición paradójica de la mímesis también está presente en Platón. Para Platón, la mímesis es el acto de copiar, y toda copia, por definición, para este filósofo, es inferior e imperfecta con respecto al original que imita. Platón critica la mímesis por ser un tipo de acción (poiésis) que, en muchos casos, impide el acceso a la idea original, o al origen de lo real que es la Idea.

Platón analiza la mímesis desde la perspectiva ontológica y epistemológica de la Idea como ser perfecto y realidad primera. El cosmos es una imitación producida (poïesis) por el propio Dios o Demiurgo a partir de la Idea, que es la realidad originaria que la poiésis del Demiurgo imita en el cosmos. Platón entiende que hay un segundo escalafón de imitación realizado por los seres humanos en la producción

9 Sörbom (1996), p.p. 33-40. 
(poiésis) de objetos. En este segundo escalón imitativo también rige el verbo poieîn, un verbo peculiar para la producción de cosas que, a través de la tékhnē, imita las ideas originales. Para Platón, existe un tercer y más bajo escalafón imitativo (poietikós) representado por el arte. El arte, en todas sus manifestaciones, existe como imitación de la imitación, mímesis de la mímesis. Imita al cosmos y a las obras producidas por el ser humano.

En el diálogo Sofista afirma "A propósito de todo lo que antes no es y que alguien, después, lo lleva a ser, decimos con cierto sentido, que quien lo lleva a ser lo produce (poieîn) y que lo que es llevado al ser es producido (poieîsthai)"10. De esta clasificación deduce Platón que los así denominados sofistas, además de enseñar por dinero la verdad más conveniente, son capaces de realizar imitaciones que tienen el mismo nombre que las cosas reales (mimémata kai omónyma tòn ónton) ${ }^{11}$. El sofista es capaz de imitar las cosas reales dándoles una apariencia de verdaderas y con ello iluden las personas. El arte ilusionista del sofista está asociado a su dominio magistral de la mímesis 12 .

Para Platón, existe una auténtica jerarquía de la poiêsis cuyo ápice primero está en el Demiurgo o artífice divino que hizo todas las cosas con su naturaleza; en un segundo grado están los seres humanos que necesitan producir las cosas a partir de lo que el artífice divino hizo. Habría un tercer grado de producción imitativa propia de los artistas, a los que denomina de seudo artífices. Platón concibe la mímesis en un doble juego, verticalmente es la obra que se produce cuando imita a la idea original y su naturaleza, horizontalmente reproduce una imagen (eídōlon) que copia la apariencia externa de la cosa y por ello es más imperfecta.

5. Aunque la lectura de la mímesis que Platón realiza hunde las raíces en su modelo ontológico y epistemológico, su objetivo es también político. Las implicaciones políticas de la mímesis aparecen, entre otros, en el diálogo La República, en la fase adulta del autor. Ya fue ampliamente comentada por muchos autores la importancia del cap. $\mathrm{X}$ de esta obra por la crítica que hace de la mímesis. Aunque la sentencia más conocida de este capítulo es que: "El poeta debe renunciar a la poesía como un amante que renuncia a una pasión que no le hace ningún bien"13, la argumentación de Platón contra la mímesis tiene una preocupación eminentemente política. Platón critica muchas formas de mímesis que ponen en entredicho su ontología de la forma primera o Idea perfecta. La disputa platónica contra la mímesis es también una disputa política contra los sofistas. El proyecto democrático de estos puede ser denominado por Platón de demagógico porque utilizan el arte de las apariencias, también, en la política. La política de los sofistas, que en muchos casos es

\footnotetext{
10 Platón (1950), Sofista, 219b.

11 Platón (1950), Sofista, 234b.

12 Platón (1950), Sofista, 235a-b.

13 Platón (1950), La República, X, 60e.
} 
formalmente la democracia, se diluye en el arte imitativo de las apariencias retóricas, lo que conduciría inevitablemente la democracia a la demagogia como producto (poíêsis) del arte imitativo, según Platón.

Para Platón, la política, como lo real, no se pauta por opiniones que imitan, sino que debe obedecer a padrones rígidos de verdad impuestos por la naturaleza de las cosas. El gobierno de una ciudad, según Platón, debe ser realizado por aquellos que tienen el saber verdadero de las cosas y no por las opiniones de la mayoría, ya que la mayoría no tiene el conocimiento verdadero de lo que es gobernar. El arte, en sus diversas manifestaciones, es una mímesis que políticamente conduce, en muchos casos, a la demagogia retórica, o a la retórica como arte mimético que ilude los ingenuos.

Platón utiliza, en el libro X de La República, la comparación entre el obrero que fabrica una cama y el pintor que la representa. El obrero fabrica la cama imitando la idea que tiene de ella. El ser original es la idea, la cama fabricada es una imitación de esa idea y como tal no es la idea, sino una copia inferior de ella. De forma irónica, define al pintor como un obrero capaz de hacer todo lo que los otros hacen separadamente, imitando en la pintura las cosas hechas en la realidad. La belleza de una pintura no podrá suplir la realidad de que esa cama no existe como tal a no ser en la forma de pintura. La imitación de la pintura es un espejismo que nos hace creer en su realidad sin que ella sea real. Para Platón, el arte ilude los ingenuos haciéndoles creer que es lo real. "Por consiguiente, el arte de la imitación se encuentra alejado de lo verdadero y al parecer realiza tantas cosas por el hecho de que alcanza sólo un poco de cada una y aún este poco es un simple fantasma" 14 .

Este trastrocar mimético de lo real por lo figurado, del ser por su imagen, es propio de los sofistas y su retórica política. Para Platón, la realidad está más allá de la mímesis, por lo que el acceso a lo real supone superar la dimensión mimética15. El famoso mito de la caverna, del libro VII de La República, adquiere todo su significado ontológico y epistemológico cuando se lo interpreta como una crítica a la reproducción mimética de las sombras que impiden reconocer el ser original de las ideas. Lo que está en cuestión en la caverna es una determinada perspectiva de la función mimética que perturba el verdadero conocimiento y desvía las personas del ser verdadero. Las sombras representan el lado irreal de la comprensión de las ideas. Seguir a las sombras es imitar una versión equivocada de lo real. Este tipo de mímesis aliena las personas de la realidad.

La degradación epistemológica de lo real provocada por la mímesis es, para Platón, un peligro político. Ella, la mímesis, debe ser apartada de la pólis por todos los medios. La presencia del arte en la pólis representa la hegemonía de la actitud imitativa en detrimento del conocimiento verdadero de lo real. Esa prevalencia

14 Platón (1950), La República, 597e.

15 Sobre la repercusión política de la mimesis en Platón, cf. Gagnebin (1993), p. 68. 
mimética destruye el uso de la razón y entorpece la creación de buenas leyes. Platón la considera una especie de vicio que pervierte la racionalidad, incluso de los más conscientes, pues el arte imitativo lleva a confundir imágenes con realidad estimulando la parte irracional. Aquí se encuentra, también, el origen del mal en la polis, para este filósofo.

Por tal motivo no debemos ofrecer entrada al arte en una ciudad con buenas leyes, porque despierta y alimenta el vicio y, dándole fuerzas destruye también el principio de lo racional, no de otro modo que lo haría cualquier ciudadano que, revistiendo de autoridad a los malvados, traicionase a la ciudad. Y destruyese a los bien dotados, hay lugar para decir que el poeta imitativo introduce en el alma de cada uno un régimen miserable, complaciendo a la parte irracional de aquella, que no es capaz de distinguir lo grande de lo pequeño y sí de pensar las mismas cosas unas veces como grandes y otras veces como pequeñas, forjándose así nuevas apariencias alejadas por completo de la verdad. ${ }^{16}$

Entre los peligros que la mímesis ofrece a la ciudad, Platón destaca a los trágicos y los poetas. Para el autor, la mímesis puede abarcar una parte de la poesía o toda ella. En la división propuesta en su obra Politeia, III, Platón clasifica la poesía en tres estilos: el primero es la narrativa simple (haplē diēgēsis) que se encuentra representada por el ditiritambo, en esta narrativa "el propio poeta habla"17; el segundo estilo es la mímesis representada por la tragedia y la comedia, en ella el poeta "profiere un discurso como si fuese otra persona"18; el tercer estilo es el que denomina de narrativa mista (di'amphotéron), que es lo propio de la poesía épica, en este estilo el poeta hace una composición producida por una mezcla de la narrativa simple con la mímesis. 19

Volviendo al capítulo X de La República, Platón trae para la escena a Homero y Hesíodo, y se pregunta si su arte imitativa en tercer grado ha contribuido en algo para crear leyes en alguna pólis, o al menos ha ayudado en la educación de ciudadanos $^{20}$. La respuesta es negativa, ya que la poesía imitativa tiene por objeto el mero placer, algo fugaz que pasa sin dejar rastro y pervierte el verdadero conocimiento racional de lo real.

6. Platón analiza el sentido de la mímesis bajo el aspecto de la imitación del modelo, la reproducción de la igualdad, la construcción de lo idéntico, la copia en imágenes de la esencia del Ser. En la medida en que la mímesis nunca consigue

\footnotetext{
16 Platón (1950), La República, 605a-606d.

17 Platón (1950), Politeia, III, 392d10.

18 Platón (1950), Politeia, III, 393c1.

19 Platón (1950), Politeia, III, 394c4.

20 Según Penelope Murray, uno de los objetivos de la crítica de Platón a Homero es la pretensión, de Platón, de substituirlo en la influencia educativa griega, suplantando la filosofía por la poesía Murray (1996), p. 22.
} 
reproducir con exactitud el original, ni imitar totalmente el modelo, es descalificada por Platón como una acción menor del conocimiento verdadero.

A pesar de las severas críticas de Platón a la mímesis, encontramos en Platón perspectivas positivas de la misma. El hecho de reconocerla como realidad y hábito humano que no puede ser dejado de lado, muestra que, para Platón, la mímesis es una práctica que está presente de muchas formas en la acción humana; es un tipo de acción (poiésis) que Platón no desconoce ya que atraviesa todas las culturas e impregna muchas formas humanas de ser. Platón da una importancia paradoxal a la mímesis: dedica amplios esfuerzos para criticarla y desconstruirla en muchas de sus versiones y, concomitantemente, la valora en cuanto acción propia del filósofo verdadero. Ese empeño filosófico, muy presente en diversas obras de Platón, es un indicio de la condición paradoxal de la mímesis y de su importancia como práctica humana que no puede ser simplemente ignorada por la filosofía, siendo la filosofía, para Platón, un tipo de mímesis verdadero.

La firme crítica de Platón a la mímesis no impide que percibamos algunas brechas en su propia argumentación, que son un indicio del carácter paradójico de esta facultad humana. Aún defendiendo la expulsión de los poetas y la poesía de la pólis por obstruir la buena política y contaminar la verdadera razón, Platón reconoce, de forma tardía, que algunos poetas, entre ellos Homero, podrán ser admitidos en la pólis. Serán aquellos que imiten valores éticos verdaderos y eleven la racionalidad por el camino de la verdad. Estos poetas podrán ser aceptados porque motivarán a los adolescentes a realizar el bien y les elevarán el espíritu fomentando acciones reales. Porque, "Homero es el más grande y primero de los trágicos" 21 puesto que "en nuestra ciudad sólo convendrá admitir los himnos a los dioses y los elogios a los hombres esclarecidos"22.

Por otro lado, y en una especie de vuelta de tuerca paradójica de la mímesis sobre sí misma, muchos comentaristas ya observaron que la filosofía de Platón recurre permanentemente a la mímesis como medio para explicar su teoría del conocimiento $^{23}$. La creencia en la existencia de una Idea perfecta de cada cosa induce Platón a concebir el pensamiento humano como una constante reproducción del ideal. Lo paradójico es que, a pesar de sus críticas a la mímesis, el filósofo afirma que el pensamiento y las acciones humanas son una mímesis del ideal24. Esta tensión paradójica atraviesa una gran parte de la filosofía de Platón y le llevará a distinguir entre varios tipos de mímesis. Según el autor, la propia noción de mímesis también puede ser extendida a la filosofía. En la Politeia, al definir el modelo de poíêsis que debe ser adoptado por el filósofo, Platón distingue, por un lado, la poíe-

\footnotetext{
21 Platón (1950), La República, X, 607a.

22 Platón (1950), La República, X, 608c.

23 Tate (1928), pp.16-23. Mazzarelli (1996), pp. 263ss.

24 Gagnebin (1993), p. 69.
} 
sis tradicional que se caracteriza por la mimetización superficial de los objetos, por la imitación de las apariencias sin captar lo que tienen de verdadero 25 ; esta poíésis contiene una naturaleza falsa y engañadora 26 . Para Platón, habría otro tipo de poíesis que es la propia del filósofo y se caracteriza por tornarse, por medio de la mímesis adecuada, lo más semejante posible a las realidades ordenadas por la razón. Según esta división, el filósofo también es un mimētēes, sin embargo su poiêsis se diferencia de las otras formas miméticas porque él se guía por la razón, por lo que Platón denomina al filósofo de ordenado y divino: "ordenado y divino, tanto cuanto es posible un hombre venir a serlo"27.

En el diálogo Sofista también desarrolla la misma tesis, según la cual habría una mímesis más auténtica que consigue reproducir con mayor fidelidad las formas ideales, esa es la mímesis filosófica ${ }^{28}$. En contraposición, existen las otras mímesis que sólo reproducen simulacros y sombras engañadoras de lo real ${ }^{29}$. Después de definir al sofista de cinco formas diferentes, en la sexta definición, Platón muestra al sofista como un disputador (antilégousin) que se presenta como portador de una ciencia aparente basada en la mera opinión (doxastikén). El sofista es capaz de realizar imitaciones (mimémata) que contienen el mismo nombre de las cosas reales ${ }^{30}$. Por ser capaz de imitar las apariencias e iludir con ellas, el sofista es denominado de ilusionista (gonta) y prestidigitador (thaumatopoión) ${ }^{31}$. Concluye Platón afirmando que existen dos formas de producir imágenes (eidōlopoiikēe), una primera produce una re-figuración (ekastiken) de lo real a través do lo que sería una verdadera imitación. Una segunda forma consiste en producir apariencias, espejismos, que se reproducen a través de simulacros fantásticos de lo real (phantastiké) ${ }^{32}$. El sofista pertenece a esta segunda clase de imitadores ilusionistas y simuladores, en cuanto el filósofo pertenece a la primera clase, pues consigue imitar con precisión y veracidad la verdad de las formas ideales 33 .

La argumentación de Platón se apoya en la tesis de que la mímesis es un tipo de actividad (poiésis) humana paradoxal. Aunque prevalecen los aspectos críticos de la mímesis, Platón no desconoce dimensiones positivas de esta facultad humana. La comprensión mimética de la poiésis de Platón está influida por el significado que el

\footnotetext{
25 Platón (1950), Politeia, X,598b2-4.

26 Platón (1950), Politeia, III, 387b4.

27 Platón (1950), Politeia, 500d1.

28 Platón (1950), Sofista, 235c.

29 Dada la importancia y repercusión de la obra, se convirtió en un clásico el estudio que Heidegger hizo sobre Platón en los cursos de 1924-25, cf. Heidegger (2003).

30 Platón. (1950), Sofista, 234 b

31 Platón. (1950), Sofista, 235 a-b

32 Platón. (1950), Sofista, 236 c.

33 Según Seth Berbardete, "El sofista, según Sócrates, es un phantasma del filósofo". Berbardete (2006), p. II, 112.
} 
verbo mimeîsthai y el substantivo mîmos habían adquirido en su tiempo, y, evidentemente, también influido por su modelo ontológico de las ideas. Lo que veremos ocurrir después de Platón es un ensanchamiento del sentido de la mímesis para otros campos que Platón no pensó.

\section{Conclusiones abiertas}

7. Las tensiones internas del pensamiento de Platón sobre la mímesis, ya presentes en la arqueología pre-socrática, son manifestaciones provenientes de su condición paradójica, la cual impide que su sentido pueda ser reducido a una única perspectiva axiológica. Estas tensiones insolubles son un fuerte indicio de que la mímesis es una facultad inherente al ser humano penetrada por una dimensión paradójica y agónica. Ella no es un a priori del que se puede deducir un determinado comportamiento, sino que existe a través de las prácticas históricas que la producen, por ello es susceptible de varias posibilidades de ser sin dejar de ser una práctica mimética.

El punto crucial de la tensión mimética presente, de modos diferentes, en la tradición pré-socrática y el Platón, es que la mímesis es una dimensión paradójica constitutiva del ser humano. Ella forma parte del ser y del actuar humano y se expresa como tal en la singularidad de las prácticas. La sombra de la paradoja mimética recorre la obra de Platón. Tal condición paradójica posibilita captar la mímesis como una práctica que, en muchos casos, opera como medio de "alienación" de las conciencias. La mímesis alienante, como Platón apunta, sumerge los sujetos en las sombras de las apariencias hasta el punto de hacerles confundir las apariencias con la realidad. Pero esta no es su única dimensión. Las críticas Platón a las dimensiones alienantes de la mímesis, como un modo inferior de acción poietike, no le impide reconocer y tematizar su condición paradójica de acción propia de los filósofos. La condición paradójica de la mímesis imposibilitó a Platón encerrarla en una mera poíésis de los poetas y artistas. El filósofo tiene que aceptar que la verdad alcanzada plenamente por el conocimiento filosófico sólo puede expresarse como verdadera en un tipo de reproducción de lo real. Criticando la potencia mimética de los poetas, Platón no niega la potencialidad de la mímesis para conocer la verdad. La paradoja de la mímesis atraviesa la obra de Platón, el autor critica y expulsa a todos los poetas, artistas e imitadores fuera de su República, pero, concomitantemente, la mímesis permanece, entre otros, con los filósofos. La potencia de la mímesis es abierta y puede producir realidades diferentes, en uno u otro sentido. Su condición paradójica le permite cierta versatilidad histórica, ora se presenta como una práctica de imitación alienante, ora como una práctica creativa, más allá de la mera imitación. 
8. La arqueología de la mímesis en el pensamiento pre-socrático y en Platón lejos de agotar su sentido, muestran que hay una irreparable abertura de sentido en ella. Otro ejemplo de esta abertura lo encontramos en el análisis divergente que el mayor discípulo de Platón, Aristóteles, hizo de la mímesis ${ }^{34}$. En este punto, como en otros muchos, Aristóteles corrige a su maestro presentando otra perspectiva filosófica de la mímesis, hasta el punto que, como ya fue observado por muchos intérpretes, la importancia de este giro interpretativo de Aristóteles se asemeja a la revolución kantiana ${ }^{35}$. Si para Platón la mímesis es sinónimo de sombras en la caverna, para Aristóteles la mímesis es la facultad de producir lo diferente en la imitación.

Toda filosofía se hace desde un presente y se realiza como filosofía del presente, en el estudio que presentamos no es diferente. La tensión paradójica de la mímesis también se replica en nuestras sociedades. De un lado, la mímesis se actualiza como una práctica alienante que anula al ser humano en diversas circunstancias. En nuestras sociedades contemporáneas, por ejemplo, los dispositivos miméticos son utilizados en gran escala para producir identidades masificadas ${ }^{36}$. La mímesis, por su abertura agonística, es susceptible de instrumentalización como medio de producir identificaciones de masa e identidades totalizantes. Las actuales sociedades de masas utilizan en gran escala mecanismos miméticos para normatizar los comportamientos y normalizar los individuos, sujetándolos "voluntariamente" a padrones sistémicos de conductas útiles o productivas. Los individuos masificados a través de mecanismos miméticos imitan el comportamiento exhibido en los padrones de propagandas, siguen las sombras de los modelos producidos por los medios de comunicación de masa, ajustan "voluntariamente" sus conductas a los ideales de vida del capitalismo, sin percibir las mediaciones alienantes que inducen los comportamientos.

La instrumentalización mimética forma parte de los dispositivos biopolíticos de normalización que se valen de tecnologías imitativas para inducir el comportamiento de los individuos de forma voluntaria, sujetándolos, de este modo, a padrones estructuralmente rentables o eficientes de vida ${ }^{37}$. La biopolítica moderna se caracteriza por el gobierno de la vida humana. Gobernar a los otros en el marco de socie-

\footnotetext{
34 Veloso (2004), p. 733-823.

35 Gagnebin (1993), p. 70.

36 Adorno aborda la problemática de la mímesis en su obra La dialéctica del esclarecimiento, primeramente en el análisis que realiza sobre la Odisea. En el capítulo sobre el antisemitismo, analiza cómo los fenómenos contemporáneos de masa, específicamente el nazismo y el antisemitismo, tienen en su base una función mimética en que los sujetos se anulan y son anulados en sus diferencias, para remitirse a una identidad totalitaria. Adorno y Horkheimer (2006).

37 Aunque M. Foucault no desarrolló análisis específicos sobre la mímesis, sus estudios sobre os dispositivos biopolíticos de normalización se explican también a partir de las técnicas de reproducción mimética que los individuos reproducen al sujetarse "voluntariamente" a los modelos prescritos por las instituciones modernas. Foucault ( 2004).
} 
dades formalmente democráticas, es una contradicción difícil de resolver ya que debe mantener un mínimo de libertad formal, pero debe ajustar a libertad de los individuos a las exigencias del sistema. El umbral donde se consigue mantener el mínimo de formalidad "democrática" con el máximo de gobierno de los otros es en la adhesión voluntaria de los individuos. Tal adhesión, lejos de ser una construcción autónoma del sujeto, es, en muchos casos, producida a través de complejas tecnologías de fabricación de deseos que diseñan el comportamiento de las voluntades. Los dispositivos de gobierno contemporáneos operan sobre la voluntad de los sujetos, intentando ajustar sus conductas a los objetivos y metas institucionalmente previstos. Las técnicas miméticas son ampliamente utilizadas para conseguir ese gobierno de las voluntades. La imitación de las sombras proyectadas por las propagandas, por ejemplo, reproduce la mímesis en su modalidad de acción alienante, sin que los sujetos la perciban como tal.

La economía política moderna utiliza ampliamente técnicas miméticas en la administración de la vida humana. La economía política se caracteriza por administrar la vida humana como recurso natural útil y productivo. Como en la oíkos clásica, la vida humana es un elemento que debe ser gestionado con sabiduría y eficiencia. En la actualidad, la forma oikonomiká de gobierno requiere la cooperación activa y voluntaria de los sujetos ${ }^{38}$. Hay un fondo sutilmente autoritario en estas formas económicas de gobierno de los otros, que queda oculto en las técnicas direccionadas a conseguir una sujeción voluntaria. La mímesis tiene un papel fundamental en esas técnicas biopolíticas de sujeción voluntaria. Los individuos son instigados a través de una constelación de técnicas de propaganda, normatividades, padrones de conducta, a subjetivarse de una determinada forma. Casi todos los métodos modernos de administración, gestión y gobierno de personas incluyen técnicas miméticas a través de las cuales se diseña en los individuos comportamientos a imitar, metas a conseguir, objetivos a desear, valores para asumir, actitudes convenientes, etc. Resulta obvio que la lógica que legitima la producción mimética de subjetividades en nuestras sociedades capitalistas es el utilitarismo y la eficiencia productiva. La inducción mimética de subjetividades normalizadas se justifica en la medida que ellas se tornan más productivas y eficientes, ofreciéndoles como recompensa una mayor inclusión social en el nivel de consumo y renta.

9. La mímesis, lejos de anularse en la unilateralidad de la copia imperfecta de lo real o en la práctica alienante de las conciencias, se manifiesta, también, como posibilidad creativa de producir reproduciendo, ella es una dimensión humana con potencialidades abiertas de ser. En esa condición, la mímesis posibilita el aprendizaje a través de la apropiación imitativa de saberes, habilidades y prácticas ${ }^{39}$. Todo

\footnotetext{
38 Foucault (2004b).

39 Para Aristóteles, la mímesis es una facultad inherente al aprendizaje humano "El imitar es congénito al hombre, en eso difiere de los otros vivientes, pues, y por imitación aprende sus primeras nociones", Aristóteles (1974), 1448b.
} 
aprendizaje incluye algún tipo o grado de apropiación imitativa de aquello que se aprende. El aprender posibilita al sujeto incorporar conocimientos y habilidades acumuladas históricamente y con ello catapultarse en poco tiempo a través de siglos de duras y difíciles conquistas humanas. El aprendizaje incorpora una dimensión mimética, sin que con ello la mímesis se reduzca a mera reproducción de lo igual. Aprender es apropiarse creativamente del modelo. La mímesis, en este caso, opera como una facultad creativa que se apropia imitando e imita creando. El verdadero aprendizaje no se limita a imitar o reproducir, sino que imita y reproduce creando sentidos nuevos para lo aprendido ${ }^{40}$. En este aspecto, la mímesis es una dimensión humana que potencializa al sujeto posibilitando la apropiación imitativa de aquello que considera pertinente; toda apropiación imitativa es también una recreación de sentido. La potencialidad mimética de reproducir creativamente no impide reconocer que la misma mímesis es susceptible de reducción instrumental a mera imitación de modelos dados.

La biopolítica también carga en su seno la paradoja. El gobierno de la vida humana, instrumentalizado económicamente por las sociedades modernas, produjo una valorización de la vida como categoría política, algo que las sociedades anteriores no tenían. La valorización de la vida se tornó una referencia ético-política a partir da cual se construyeron nuevos discursos y prácticas de resistencia a sus dispositivos de control. Las nuevas luchas políticas contemporáneas enarbolan, cada vez menos, las clásicas banderas de los ideales universales: libertad, igualdad, justicia, y cada vez más se entablan entorno a la dignidad de la vida humana. La vida humana, instrumentalizada miméticamente para sujetar los individuos, se revela paradójicamente como criterio político para desconstruir las tecnologías de control.

Estas prácticas de resistencia de la vida también utilizan la mímesis como dispositivo para producir comportamientos alternativos a las formas de control social. El aprendizaje envuelve siempre una parte de imitación. Aprender a resistir significa, también, imitar creativamente otras formas de resistencia. Los discursos y prácticas de defensa de los derechos humanos, bioética, ecología, anti-racismo, etc., cargan en su seno la paradoja de la instrumentalización y la emancipación, pero a pesar de ello, o tal vez por causa de esa condición paradójica, son el nuevo campo de dis-

\footnotetext{
40 Walter Benjamín es un autor contemporáneo que destaca la dimensión productiva de la mímesis en el aprendizaje humano. Tomando como modelo el aprendizaje mimético de los niños, Benjamín subraya el papel de la mímesis en relación al lenguaje humano. Sus tesis son expuestas inicialmente en dos ensayos "Del lenguaje general y del lenguaje del hombre (1916), y "La tarea del traductor" (1921) complementados con otros dos escritos de 1933, "Doctrinas de lo semejante" y "Sobre la capacidad mimética" cf. Benjamin, W.( 2001). Sobre El Lenguaje En General Y Sobre El Lenguaje De Los Humanos. In: Benjamin, Walter. Para Una Crítica De La Violencia y otros ensayos. Iluminaciones IV. Madrid: Taurus. Benjamin, W. (1977). Gesammelte Schriften II-I. Unter Mitwirkung von Theodor W. Adorno und G.Scholem; herausgegeben von Rolf Tiedemann und Hermann Schweppenhäuser. Frankfurt: Suhrkamp.
} 
puta política donde se deslindan las formas políticas de resistencia. La mímesis también juega un papel relevante en el aprendizaje y en la reproducción creativa de estas nuevas formas de resistencia adaptadas a contextos y coyunturas diferentes. Incluso, las formas de emancipación contemporáneas también utilizan técnicas miméticas que reproducen tácticas de acción y técnicas alternativas a los dispositivos de control dominantes. La reproducción creativa de las formas de resistencia posibilita adaptar tipos de acción a coyunturas diferentes y reproducir innovadoramente tácticas diferentes en contextos diferentes. La versatilidad de los movimientos sociales contemporáneos obedece mucho a su capacidad mimética de reproducir creativamente antiguas tácticas de acción en nuevos contextos políticos.

La condición paradójica de la mímesis posibilita sus diversos modos de ser impidiendo el reduccionismo unilateral. El punto crítico de la mímesis no se encuentra en la disyuntiva de elegir entre alguna de sus posibilidades históricas, sino en la potencialidad abierta por la tensión agonística que la atraviesa. Esta perspectiva nos permite comprender su naturaleza histórica, sin que por ello el sentido de la mímesis se agote en la mera descripción sociológica de sus modos de ser. $\mathrm{Su}$ potencia se manifiesta en el eje tensional que le permite constituirse históricamente como potencialidad de la acción humana que cristaliza de formas diversas, incluso contradictorias. No hay una verdad única de la mímesis, o una mímesis verdadera e otra falsa, sino que la condición paradójica le permite expresarse en algunos casos como imitación alienante de sombras y en otros como imitación creativa de semejanzas. La verdad de la mímesis no está en una de las disyuntivas, sino en la posibilidad de crear disyuntivas o de crearse históricamente como una forma histórica diferente. La condición paradójica del ser humano hace posible que la mímesis se exprese como convergencia tensional capaz de asimilar al otro miméticamente o práctica que le permite distinguirse de él a través de la diferenciación mimética. Las repercusiones ético-políticas de esta perspectiva agonística quedan evidentes, así como sus implicaciones estéticas.

\section{Referencias bibliografícas}

Adorno, T. y Horkheimer M. (2006): Dialética do esclarecimento. São Paulo: Jorge Zahar.

Aristóteles (1974): Poética. Tradução trilíngüe grego, latim e espanhol de Valentín García Yebra. Madrid: Gredos.

Benjamin, W. (2001): "Sobre el lenguaje en general y sobre el lenguaje de los humanos". In: Benjamin, W. Para una crítica de la violencia y otros ensayos. Iluminaciones I. Madrid: Taurus. 
Benjamín, W. (1977): Gesammelte Schriften II-I. Unter Mitwirkung von Theodor W. Adorno und G. Scholem; herausgegeben von Rolf Tiedemann und Hermann Schweppenhäuser. Frankfurt: Suhrkamp.

BlACK, D. L. (1990): Logic and Aristotle's Rhetoric and Poetics in Medieval Arabic Philosophy, Leiden, Brill.

Berbardete, S. (2006): The Being of the Beautiful: Plato's Theatetus, Sophist, and Stateman. Chicago: The University of Chicago Press.

Callois, R. (2002): "Mimétisme et physcasténie légendaire". In: Id. Le mythe et l'homme. Paris: Gallimard.

ElSE, G. F. (1958): "Imitation in the Fith Century". Classical philology, V. LIII, N. 2, April.

Foucault, M. (2004): Sécurité, Territoire, Population. Paris: Seuil.

Foucault, M. (2004b): Naissance de la biopolitique. Paris: Seuil/Gallimard.

FRÜRCHTL, J. (1986): Mimesis - Konstellation eines Zentralbegriffs bei Adorno. S.1.: Konigshaus und Neumann.

Gagnebin, J. M. (1993): "Do conceito de mímesis no pensamento de Adorno e Benjamin”. In: Perspectivas. São Paulo.

Hallwel, S. (2002): The Aesthetics of mimesis: Ancient texts \& modern problems. Princeton: Princeton University Press.

Heidegger, M. (2003): Plato's Sophist. Bloomington: Indiana University Press. IrigoIn, J. (1997): Tradition et critique des textes grecs, Paris, Les Belles Lettres. Mazzarelli, C. (1996): Platone. Tutti gli scritti a cura di Giovani Reali. Milano: Rusconi.

MorauX, P. (2003): Les listes anciennes des ouvrages d'Aristote, Louvain, Éditions Universitaires de Louvain.

Murray, P. (Ed.) (1996): Plato on Poetry. New York; Melbourne: Cambridge University Press.

Nussbaun, M. C. (1995): The fragility of goodness. Luck and ethics in greek tragedy and hilosophy. Cambridge: Cambridge University Press.

Platón (1950): Oeuvres complètes. Trad. fr. par L. Robin. Paris : Bibliothèque de la Pléiade.

TAte, J. (1928): Plato's Republic. Classical Quarterly.

SörBom, G. (1996): Mimises and art; Studies in the Origin and Early development of an Aesthetic. Upsala: Svenska Bokförlaget Bonniers.

Veloso, C.W. (2002): “La Poetica: scienza produttiva o logica?", in D. Lanza (ed.), La Poetica di Aristotele e la sua storia. Atti della Giornata internazionale di studi in memoria di Viviana Cessi, Università degli Studi di Pavia, Pisa, ETS.

Veloso, C. W. (2004): Aristóteles Mimético. São Paulo: Discurso Editorial.

WoodrufF, P. (1992):“Aristotle on Mimesis”. In A. O. Rorty (ed) Essays on Aristotle's Poetics. Princeton: Princeton University Press. 
Wulf, Ch. (2008): “Mimetic Learning”. Designs for Learning, V. 1, Number 1, March.

Castor M. M. Bartolomé Ruiz

Facultad de Filosofía

Universidad Unisinos, Brasil

castorbartolome@terra.com.br 